\title{
The Effectiveness of the "Tax Telling" microsite in Improving Tax Knowledge of Senior High School Students
}

\author{
${ }^{1}$ Dewi Kusuma Wardani, ${ }^{2}$ Titi Aprianingsih \\ 123wi_kusuma@yahoo.co.id, 2titiaprianingsih127@gmail.com \\ ${ }^{1,2}$ Faculty of Economics, Universitas Sarjanawiyata Tamansiswa
}

\begin{abstract}
The "Tax Telling" microsite is the program to educate student about tax using microsite. This study aims to determine the effectiveness of the "Tax Telling" microsite in improving tax knowledge of senior high school students. The study used two school, one school that received the "Tax Telling" microsite and the other did not get the "Tax Telling" microsite. The study compared student's tax knowledge in both schools. "Tax Telling" microsite can improve student's tax knowledge. Using t-test, the result showed that student's tax knowledge in school that received the "Tax Telling" program were same with student's tax knowlede in school that did not get the program. It implies that the "Tax Telling" microsite was ineffective to improve the student's tax knowledge.
\end{abstract}

Keywords:tax telling; microsite; tax knowledge; effectivenes; students

\section{Introduction}

The number of taxpayers in Indonesia is increasing, but it is not offset by tax payer's compliance [1]. The low compliance is shown by the high tax amnesty participants who admit their mistakes in hiding property to avoid taxes that must be paid. One of the causes of this disobedience is the lack of knowledge in paying taxes [2]. To increase tax knowledge, the government has made many efforts, such as tax socialization, but the results have not been effective[3][4]. The ineffectiveness of this socialization was due to not being carried out early [5].

To increase tax knowledge, the government carried out a variety of programs, one of which was "Taxes Telling" intended for prospective taxpayers, i.e. school students and undergraduate students. "Tax Telling" microsite gives tax education to students from elementary school until university. It consist of infographics, education news, event calendars, and materials that can be downloaded. The government uses microsite for the tax education media because the young generations are more familiar with this media than the traditional media, like books, newspapers, and television.

Tax knowledge is the process of changing attitudes and behavior of a taxpayer or a group of taxpayers in an effort to mature humans through training and teaching efforts [1][6]. With increasing taxation knowledge, there is also an increase in awareness to pay taxes [5][7].

One of the goals of the "Tax Telling" microsite is to provide an understanding of tax as the main pillar of the country's development. Understanding of taxation can be done by providing tax knowledge through tax socialization [2]. Knowledge of taxation is the process by which taxpayers know about taxation and apply that knowledge to pay taxes [8]. This taxation knowledge is not only a conceptual understanding based on the Taxation Law, 
Minister of Finance Decree, Circular, Decree but also the demands of the ability or technical skills how to calculate the amount of tax owed [9][5].

Different levels of taxpayers understanding will affect the taxpayer's assessment to behave obediently in carrying out tax obligations [9][10]. The high level of taxpayer's understanding will make the taxpayer choose to behave obediently in carrying out tax obligations.

The researchers proved that the higher taxation socialization will increase taxpayer knowledge and understanding. It can expand tax knowledge and taxpayer's understanding [11][5]. The researcher is [5] which states that tax socialization has a direct influence on the understanding of taxpayers. After tax socialization, prospective tax payers will get taxation knowledge and will improve their understanding about tax obligation [5]. [1][11] also stated that tax socialization has a positive effect on tax knowledge. Based on the theory and the results of previous studies, there is a positive relationship between the "Tax Telling" microsite and the knowledge of taxation.

The remainder of the paper is structured as follows. Section 2 research method. Section 3 discusses the results and discussion. Last, section 4 presents the conclusions.

\section{Material \& Methodology}

The population is all of senior high school students. With convenience sampling method, this research 2 senior high school, with 61 respondents. The data source is the primary data, with questionnaires as data collection method.

This study uses 1 independent variables, tax knowledge. It is measured using three indicators, i.e. taxation functions, taxation regulations, and registration mechanisms as taxpayers [12]. Researchers conduct a pilot test to find out whether the instrument is feasible to use in actual research. Based on validity result, all of items are valid. Based on Cronbach Alpha, each variable is reliable.

This research uses independent sample t-test. Before that, researchers do a classical assumption test, ie normality.

\section{Results and Discussion}

Because the Pearson-correlation values are above r-table, all items are valid. Because of Cronbach Alpha value higher than 0.006 (ie 0,845), the items are reliable.The data in this study are stated normally distributed. This is indicated by the value Kolmogorov-Smirnov of 0,776 and a significance value of 0,584 which means greater than alpha value 0.05 .

Table 1. Descriptive Statistic

\begin{tabular}{ccc}
\hline & $\begin{array}{c}\text { School with the "Tax } \\
\text { Telling" microsite }\end{array}$ & $\begin{array}{c}\text { School without the "Tax } \\
\text { Telling" microsite }\end{array}$ \\
\hline $\mathrm{N}$ & 30 & 31 \\
\hline Mean & 34.93 & 36.00 \\
\hline $\begin{array}{c}\text { Std. } \\
\text { Deviation }\end{array}$ & 4.835 & 3.651 \\
\hline $\begin{array}{c}\text { Std. Error } \\
\text { Mean }\end{array}$ & .883 & .656 \\
\hline
\end{tabular}

Table 1 shows that the number of school student respondents with a "Tax Telling" microsite and the number of respondents without a "Tax Telling" microsite has almost the 
same, namely 30 students and 31 students. The average value of taxation knowledge of both schools is also almost the same, namely 34.93 and 36.00.

Table 2. Data Frequency Distribution For School Student's with Tax Telling Microsite

\begin{tabular}{cccc}
\hline Category & Low & Medium & High \\
\hline Range & $24-31$ & $32-39$ & $40-47$ \\
\hline Frequency & 7 & 18 & 5 \\
\hline Percentage & $23,33 \%$ & $60,00 \%$ & $16,67 \%$ \\
\hline
\end{tabular}

Table 2shows that prospective taxpayers in school with "Tax Telling" microsite, have the knowledge to pay moderate taxes with a percentage of $60,00 \%$.

Table 3. Data Frequency Distribution For School Student's without Tax TellingMicrosite

\begin{tabular}{cccc}
\hline Category & Low & Medium & High \\
\hline Range & $26-32$ & $33-39$ & $40-46$ \\
\hline Frequency & 15 & 15 & 1 \\
\hline Percentage & $48,39 \%$ & $48,39 \%$ & $3,23 \%$ \\
\hline
\end{tabular}

Table 3 shows that prospective taxpayers in school without "Tax Telling" micrositehave the knowledge to pay low and medium taxes with the same percentage of $48,39 \%$.

Table 4. Independent t-test

\begin{tabular}{|c|c|c|c|c|}
\hline & & & $\begin{array}{c}\text { Equal variances } \\
\text { assumed }\end{array}$ & $\begin{array}{c}\text { Equal variances } \\
\text { not assumed }\end{array}$ \\
\hline \multirow{2}{*}{$\begin{array}{l}\text { Levene's } \\
\text { Test for } \\
\text { Equality of } \\
\text { Variances }\end{array}$} & \multicolumn{2}{|c|}{$\mathrm{F}$} & 1.230 & \\
\hline & \multicolumn{2}{|c|}{ Sig. } & .272 & \\
\hline \multirow{7}{*}{$\begin{array}{l}\text { t-test for } \\
\text { Equality of } \\
\text { Means }\end{array}$} & \multicolumn{2}{|c|}{$\mathrm{t}$} & 1.656 & 1.649 \\
\hline & \multicolumn{2}{|c|}{ Df } & 59 & 54.892 \\
\hline & \multicolumn{2}{|c|}{ Sig. (2-tailed) } & .103 & .105 \\
\hline & \multicolumn{2}{|c|}{ Mean Difference } & 1.837 & 1.837 \\
\hline & \multicolumn{2}{|c|}{ Std. Error Difference } & 1.109 & 1.114 \\
\hline & \multirow{2}{*}{$\begin{array}{c}95 \% \\
\text { Confidenc } \\
\text { e Interval } \\
\end{array}$} & Lower & -.383 & -.395 \\
\hline & & Upper & 4.056 & 4.068 \\
\hline
\end{tabular}

Table 4 shows the significance result of 0.103 is greater than alpha 0.005 . This indicates that there is no difference in knowledge between students in schools with"Tax Telling" microsite and the knowledge of students in schools that do not learn with that microsite. The absence of this difference because the tax curriculum is actually already included in the subjects of economics and entrepreneurship.This result rejects the hypothesis that says "tax telling" microsite increases the knowledge of taxation of senior high school students. This results indicates that the "Tax Telling" microsite is not effective to improve the high school students" knowledge of taxation.

The "Tax Telling" microsite is a socialization for prospective taxpayers in senior high school with social media, i.e. microsite. Although intended to increase tax knowledge for prospective taxpayers, the "Tax Telling" microsite does not provide all of taxation information, such as taxation functions, taxation regulations, and registration mechanisms as 
taxpayers. The "Tax Telling" microsite only emphasizes the socialization of the tax function only to foster awareness. This causes students who get the "Tax Telling" microsite also do not have knowledge about tax regulations and the mechanism of registration as a taxpayer.

\section{Conclusion}

The "Tax Telling" microsite is the program to educate student about tax[1][11]. This study aims to determine the effectiveness of the "Tax Telling" microsite in improving tax knowledge of senior high school students. The study used two school, one school that learn taxation with the "Tax Telling" microsite and the other did not learn taxation with the "Tax Telling" microsite. The study compared student's tax knowledge in both schools. Using "Tax Telling" micrositecan improve student's tax knowledge. Using t-test, the result showed that student's tax knowledge in school that received the "Tax Telling" where same with student's tax knowledge in school that did not use that microsite. It implies that the "Tax Telling" microsite is ineffective to improve the student's tax knowledge. The next research should explore whether the "Tax Telling" microsite can increase awareness of paying taxes, voluntary care to pay taxes, and the intention to pay taxes.

\section{References}

[1] Hastuti, "Tax Awareness And Tax Education: A Perception Of Potential Taxpayers," Int. J. Business, Econ. Law, vol. 5, no. 1, p. 9, 2014.

[2] D. K. Wardani and E. Wati, "Pengaruh Sosialisasi Perpajakan terhadap Kepatuhan Wajib Pajak dengan Pengetahuan Perpajakan sebagai Variabel Intervening ( Studi Pada Wajib Pajak Orang Pribadi di KPP Pratama Kebumen )," J. Nominal, vol. VII, no. 1, pp. 33-54, 2018.

[3] S. Tambun and Y. Kopong, "the Effect of E-Filing on the of Compliance Individual Taxpayer , Moderated By Taxation Socialization," South East Asia J. Contemp. Business, Econ. Law, vol. 13, no. 1, pp. 45-51, 2017.

[4] M. E. Kornhauser, Normative and Cognitive Aspects of Tax Compliance: Literature Review and Recomendations for IRS Regarding Individual Taxpayers. 2007.

[5] L. Koster, "The Incorporating of Basic Tax Education in the Secondary School Curriculum," Thesis Univ. Pretoria, no. 23135914, pp. 1-74, 2012.

[6] E. Savitri and Musfialdy, "The Effect of Taxpayer Awareness, Tax Socialization, Tax Penalties, Compliance Cost at Taxpayer Compliance with Service Quality as Mediating Variable," Procedia - Soc. Behav. Sci., vol. 219, no. December, pp. 682687, 2016.

[7] P. Fauziati, A. F. Minovia, R. y. Muslim, and R. Nasrah, "The Impact of Tax Knowledge on Tax Compliance Case Study in Kota Padang, Indonesia Akademia Baru," J. Adv. Res. Bus. Manag. Stud., vol. 2, no. 1, pp. 22-30, 2016.

[8] A. Pratama, "Individual Taxpayer Characteristics and Taxpayer Knowledge: Exploratory Survey on Individual Taxpayers in Bandung City, Indonesia," Rev. Integr. Bus. Econ. Res., vol. 7, no. 1, pp. 5-345, 2018.

[9] G. D. Myles, "Experimental Evidence on Tax Compliance," Tax Adm. Res. Cent., no. February, 2014.

[10] K. R. Kipsigei, "Taxpayers Compliance Behavior with Tax System: A Survey of Small and Medium Enterprises in Kericho Town, Kericho District," Thesis Univ. Nairobi, pp. 1-53, 2011.

[11] I. Mukhlis, S. H. Utomo, and Y. Soesetio, "The Role of Taxation Education on 
Taxation Knowledge and Its Effect on Tax Fairness as well as Tax Compliance on Handicraft SMEs Sectors in Indonesia," Int. J. Financ. Res., vol. 6, no. 4, pp. 161$169,2015$.

[12] M. A. L. I. A. Al-zaqeba, S. A. Hamid, and I. Muhammad, "TAX COMPLIANCE OF INDIVIDUAL TAXPAYERS : A SYSTEMATIC," Proc. IIER Int. Conf. 2018, vol. I, no. April, pp. 42-52, 2018. 